Jurnal Sain Veteriner, Vol. 37. No. 1. Juni 2019, Hal. 11-16

DOI : $10.22146 /$ jsv. 27680

ISSN 0126-0421 (Print), ISSN 2407-3733 (Online)

Tersedia online di https://jurnal.ugm.ac.id/jsv

\title{
Uji Ekstrak n-Hexana Rumput Kebar (Biophytum petersianum Klotzsch) pada Tikus Wistar Hiperkolesterolemia
}

\section{Test of the n-Hexane Extract of Rumput Kebar (Biophytum petersianum Klotzsch) on High Cholesterol Wistar Rats}

\author{
Priyo Sambodo ${ }^{1}$, Purwaningsih ${ }^{1}$, Alnita Baaka ${ }^{1}$, Trini Susmiati ${ }^{2}$, Claude Mona Airin ${ }^{3 *}$ \\ ${ }^{1}$ Program Studi Diploma 3 Kesehatan Hewan, Fakultas Peternakan, Universitas Papua \\ Jl. Gunung Salju, Amban, Manokwari, Papua Barat, 98314, Indonesia \\ ${ }^{2}$ Departemen Biokimia, ${ }^{3}$ Departemen Fisiologi, Fakultas Kedokteran Hewan, \\ Universitas Gadjah Mada \\ Jl. Fauna No. 2, Karangmalang, Yogyakarta, 55281, Indonesia \\ *Email: monaairin@ugm.ac.id
}

Naskah diterima : 23 Agustus 2017, direvisi : 9 Desember 2018, disetujui : 9 Desember 2018

\begin{abstract}
This study was aimed to determine the secure level of the n-hexane extract of kebar grass on hypercholesterolemia rats based the acute oral toxicity test. Based the literature, no report on the toxic dosage before, initial dose was started at $300 \mathrm{mg} / \mathrm{kg}$ body weight (BW) and to be increased 2000 to $5000 \mathrm{mg} / \mathrm{kg}$ BW. Toxicity data were set for 24 hours and continued until 14 days after treatment for several parameters, i.e : toxicity symptoms, death of animals, changes in body weight and the manifestation of toxicity effects. At the end of the test, the rats were sacrificed and organs were taken for abnormalities (macroscopy). The results of this study showed that the administration of the $n$-hexane extract of grass kebar at all doses did not show the toxicity symptoms, mortality and body weight change. The absolute and relative weights and gross pathology observation of the internal organ were normal. Conclusions: the n-hexane extract of grass kebar is safe and the $\mathrm{LD}_{50}$ was determined on category 5 , unclassified or minimum practically non toxic
\end{abstract}

\begin{abstract}
Abstrak
Penelitian ini bertujuan untuk mengetahui tingkat keamanan ekstrak n-hexana rumput kebar pada tikus hiperkolesterolemia menggunakan metode uji toksisitas akut oral. Berdasarkan literatur, tidak ada laporan mengenai dosis toksisitas sehingga starting dosis dimulai pada limit test $300 \mathrm{mg} / \mathrm{kg} \mathrm{BB}$ dan jika perlu ditingkatkan ke dosis 2000$5000 \mathrm{mg} / \mathrm{kg}$ BB. Data gejala toksik dan kematian hewan ditetapkan selama 24 jam setelah perlakuan dan pengamatan uji tetap dilanjutkan sampai 14 hari setelah perlakuan sediaan uji. Selama 14 hari dilakukan pengamatan gejala-gejala toksik, kematian hewan uji, perubahan kenaikan berat badan dan manifestasi efek toksik. Pada akhir uji, tikus dikorbankan dan diambil organ vitalnya dan dievaluasi terhadap kelainan gross patologi (makroskopi). Hasil penelitian menunjukkan pemberian ekstrak n-hexana rumput kebar pada dosis limit test $300 \mathrm{mg} / \mathrm{kg}$ BB dan 5000 $\mathrm{mg} / \mathrm{kg}$ BB tidak menimbulkan gejala toksik maupun kematian hewan uji. Pada organ vital tidak ditemukan adanya perubahan. Analisis statistik menunjukkan tidak ada perbedaan yang signifikan pada berat badan, berat absolut organ dan berat relatif organ antara kelompok kontrol dan perlakuan. Kesimpulan: pemberian ekstrakn-hexana rumput kebar aman diberikan pada dosis $300 \mathrm{mg} / \mathrm{kg} \mathrm{BB}, 2000 \mathrm{mg} / \mathrm{kg}$ BB dan $5000 \mathrm{mg} / \mathrm{kg}$ BB secara peroral
\end{abstract}

Kata kunci: hiperkolesterolemia; rumput kebar; tikus

\section{Pendahuluan}

Rumput Kebar (Biophytum petersianum

Klotzsch) merupakan salah satu spesies dari genus Biophytum dalam family Oxalidaceae yang merupakan salah satu tumbuhan endemik Indonesia (Papua) yang telah dimanfaatkan sebagai tanaman obat, khususnya oleh penduduk lokal. Biophytum diyakini memiliki potensi sebagai antihiperlipidemia 
(Kakade et al. 2015; Renuka et al. 2015). Penelitian terakhir menyebutkan bahwa ekstrak rumput kebar dapat menurunkan tingkat kolesterol total pada serum kelinci (Sambodo et al., 2015). Berdasarkan parameter darah, uji toksisitas ekstrak n-hexana rumput kebar pada tikus normal tidak menyebakan ketoksikan dan atau kematian pada hewan coba (Sambodo et al., 2016). Akan tetapi, uji toksisitas ekstrak n-hexana rumput kebar pada tikus hiperkolesterolemia belum pernah dilakukan. Oleh karena itu, penelitian ini bertujuan mengetahui tingkat keamanan ekstrak nhexana rumput kebar pada tikus hiperkolesterolemia melalui uji toksisitas akut oral berdasarkan gejalagejala toksik, berat badan, berat organ relatif dan gross patologi.

\section{Materi dan Metode}

Pada penelitian ini menggunakan tikus yang berasal dari LPPT Unit IV. Tikus dipelihara dalam kandang komunal dengan ukuran $\mathrm{p} \mathrm{x} 1 \mathrm{x} \mathrm{t}(42 \mathrm{~cm} \times$ $21 \mathrm{~cm} \times 20 \mathrm{~cm}$ ), suhu ruang pemeliharaan $22^{\circ} \mathrm{C}-15^{\circ} \mathrm{C}$, kelembaban $60 \%-70 \%$ dengan siklus cahaya 12 gelap 12 terang. Semua perlakuan dalam penelitian ini sudah mendapat persetujuan tim kelayakan etik LPPT dengan nomor 00034/04/LPPT/IX/2016.

\section{Ekstraksi Rumput Kebar}

Sejumlah serbuk rumput kebar (diperoleh dari Distrik Kebar Tengah yang terletak pada 13303"'25,8' Bujur Timur dan 0048"31,1' Lintang Selatan dengan ketinggian 590 m dpl, Kabupaten Tambrauw Propinsi Papua Barat), diidentifikasi di Herbarium Manokwariense Pusat Penelitian Keanekaragaman Hayati Universitas Papua, direndam dalam larutan ethanol (Merck ${ }^{\mathrm{R}}$ ) 50\% dan diaduk selama 30 menit dan didiamkan selama 24 jam. Selanjutnya dilakukan penyaringan menggunakan kertas saring dengan ukuran pori 2,5 $\mu \mathrm{m}$ untuk memperoleh filtrat. Proses diulang sebanyak 3 kali sehingga diperoleh filtrat hasil dari 3 kali perendaman (filtrat I) dan ampas (Yunita et al., 2009). Selanjutnya filtrat I diuapkan dengan vacuum rotary evaporator (Yamato) pemanas water bath pada suhu $70^{\circ} \mathrm{C}$, sehingga diperoleh filtrat pekat. Filtrat pekat ditambah $n$-hexana kemudian dicampur selama 5 menit dan didiamkan selama 1 jam lalu dipisahkan dengan corong pisah. Proses ini diulang sebanyak 5 kali sehingga diperoleh filtrat II dan residu. Selanjutnya filtrat II diuapkan dengan vacuum rotary evaporator pemanas water bath pada suhu $45{ }^{\circ} \mathrm{C}$ sehingga diperoleh ekstrak rumput kebar fraksi $n$ hexana (Chapagain dan Wiesman, 2005; Bogoriani, 2008).

\section{Uji Toksisitas Akut secara Oral}

Uji toksisitas akut oral dilakukan berdasarkan OECD 423 dan Peraturan Kepala Badan Pengawas Obat dan Makanan Republik Indonesia Nomor 7 Tahun 2014 Tentang Pedoman Uji Toksisitas Nonklinik Secara In Vivo. Hewan percobaan yang digunakan adalah tikus jantan galur wistar (umur 6-8 minggu). Sebanyak 18 ekor tikus dibagi secara acak ke dalam 4 kelompok yang terbagi atas 3 ekor (kelompok I), 6 eko2 (kelompok II), 6 ekor (kelompok III) dan 3 ekor (kelompok IV). Hewan uji dipelihara di dalam kandang individu. Pakan yang diberikan sebanyak $15 \mathrm{~g}$ per ekor per hari dan minum secara ad libitum .

Induksi dilakukan menurut Mamoat (2001) dengan modifikasi. Setiap kelompok hanya diberi pakan standar komersial selama 7 hari sebagai masa adaptasi. Setelah masa adaptasi seluruh kelompok diinduksi hiperlipidemia dengan pemberian kolesterol murni 0,03 gram dan minyak babi 1 gram per ekor selama 28 hari. Pada kelompok II, III dan IV diberi perlakuan fraksi $n$-hexana ekstrak rumput kebar dan kelompok I (kontrol) tidak diberikan perlakuan. Ekstrak rumput kebar dilarutkan dalam aquadest 
Uji Ekstrak n-Hexana Rumput Kebar (Biophytum petersianum Klotzsch) pada Tikus Wistar Hiperkolesterolemia

sampai volume $3 \mathrm{ml}$. Perincian perlakuan pada masing-masing kelompok adalah sebagai berikut:
A. Kelompok I
: aquades
B. Kelompok II
: fraksi $n$-hexana $300 \mathrm{mg} / \mathrm{kg}$
C. Kelompok III
: fraksi $n$-hexana $2000 \mathrm{mg} / \mathrm{kg}$
D. Kelompok IV
: fraksi $n$-hexana $5000 \mathrm{mg} / \mathrm{kg}$

Metode uji mengacu pada pada metode uji toksisitas oral 423. Dosis yang diberikan mulai dari $300 \mathrm{mg} / \mathrm{kg} \mathrm{BB}$, jika hewan coba tidak menunjukkan gejala klinis yang berarti dan tidak menimbulkan kematian maka dosis diberikan $2000 \mathrm{mg} / \mathrm{kg} \mathrm{BB}$. Dosis akan ditingkatkan menjadi $5000 \mathrm{mg} / \mathrm{kg}$ BB jika tidak muncul gejala klinis ataupun kematian. Pemeriksaan hematologi meliputi pemeriksaan kolesterol total dan trigliserida dari serum yang diambil melalui sinus orbitalis setelah hewan di anestesi dengan ketamine pada akhir masa induksi. Pemeriksaan dilakukan dengan metode chod-pap menggunakan microlab 200 diLPPTUGM

Pengamatan potensi ketoksikan dilakukan dengan menghitung jumlah hewan coba yang mati dan pengamatan gejala klinis terdiri atas pengamatan sistem tubuh yang terdiri atas aktivitas motorik, sikap tubuh, defekasi, urinasi, pernafasan dan salivasi (Diantika dan Wiwiek, 2016). Pengamatan dilakukan selama 14 hari setelah pemberian dosis tunggal ekstrak n-hexana rumput kebar (Sambodo et al., 2018) Penimbangan berat badan dilakukan untuk semua hewan coba pada hari pertama dan terakhir masa observasi.

Nekropsi hewan uji dilakukan dengan ketamine dosis lethal setelah masa observasi selesai. Pemeriksaan patologi meliputi pemeriksaan gross nekropsi (makroskopis) organ terhadap abnormalitas dan lesi. Organ internal (otak, jantung, paru, hepar, lambung, usus, ginjal, limpa) dikeluarkan dari rongga tubuh, dibersihkan dari lemak dan ditimbang (berat absolut). Berat relatif organ (BRO) diperoleh dengan rumus menurut Halim et al. (2011):

$\mathrm{BRO}=($ berat organ $(\mathrm{g}) /$ berat badan tikus mati $(\mathrm{g}) \times 100)$

\section{Analisis Data}

Semua data kuantitatif dianalisis secara statistik menggunakan SPSS 23. Data dinyatakan dalam mean \pm standar deviasi. Perbedaan dari pengaruh perlakuan yang berbeda dianalisa dengan analisis sidik ragam dan beda nyata $(\mathrm{P}<0,05)$ dilanjutkan dengan uji lanjut metode Duncan (Duncan Multiple Range Test).

\section{Hasil dan Pembahasan}

\section{Induksi Hiperkolesterolemia}

Rata-rata tingkat kolesterol total dan gliserida pada seluruh tikus setelah induksi hiperlokesterolemia masing-masing adalah 72,0 $\pm 9,8$ dan 79,9 $928,1 \mathrm{mg} / \mathrm{dl}$. Giknis dan Clifford (2008), menyatakan bahwa ratarata kolesterol dan trigliserida pada tikus jantan Wistar umur 8-16 minggu masing-masing adalah $58 \pm 13$ dan $44 \pm 21$ sehingga dapat dikatakan bahwa hewan coba mengalami hiperlokolesterolemia.

\section{Ketoksikan Akut dan Gejala Klinis}

Pada seluruh kelompok perlakuan tidak ditemukan tikus yang mati dan tidak terlihat efek ketoksikan akut selama 14 hari waktu pengamatan. Pada pengamatan fisik tidak ditemukan adanya gejalagejala keracunan seperti perubahan pada kulit dan rambut, mata dan membrana mukosa, pola tingkah laku, tremor, salivasi, diare, pingsan dan koma. Hal ini sesuai dengan hasil penelitian Oraon dan Sinha (2012), yang menyebutkan bahwa ekstrak alkohol Biophytum reinwardtii (dosis 50, 75 dan $100 \mathrm{mg} / \mathrm{kg}$ ) mungkin aman untuk tikus, dimana dari hasil uji toksisitas akut ekstrak tersebut tidak ditemukan gejala-gejala keracunan maupun kematian pada hewan coba.

Tidak ditemukannya tikus yang mati pada seluruh kelompok dapat diartikan bahwa $\mathrm{LD}_{50}$ ekstrak 
Priyo Sambodo, et. al.

n-hexana rumput kebar lebih dari $5000 \mathrm{mg} / \mathrm{kg}$ BB. Hasil tersebut berbeda dengan hasil penelitian Banerjee et al. (2014) yang menyatakan bahwa ekstrak ethanol Biophytum sensitivum DC ditemukan pada dosis $5000 \mathrm{mg} / \mathrm{kg}$ BB tikus yang diinduksi ulcer perut. Perbedaan ini diyakini disebabkan oleh perbedaan induksi yang dilakukan.

\section{Berat Badan}

Berat badan kelompok perlakuan dan kontrol ditunjukkan pada Tabel 1. Terjadi peningkatan secara bertahap pada berat badan perlakuan dan kontrol. Berat badan kelompok perlakuan tidak berbeda nyata dibandingkan dengan kelompok kontrol. Persentase peningkatan berat badan pada seluruh kelompok masing-masing adalah 15,3\%, 15,6\%, 12,7\% dan $13,0 \%$.

Tabel 1. Berat badan kelompok kontrol dan perlakuan yang diberikan ekstrak rumput kebar.

\begin{tabular}{lcc}
\hline & \multicolumn{2}{c}{ Berat Badan (gr) } \\
\cline { 2 - 3 } & Hari ke-29 & Hari ke-42 \\
\hline Kontrol & $172,93 \pm 16,34$ & $188,20 \pm 13,36$ \\
$300 \mathrm{mg} / \mathrm{kg} \mathrm{BB}$ & $166,33 \pm 13,51$ & $181,93 \pm 19,11$ \\
$2000 \mathrm{mg} / \mathrm{kg} \mathrm{BB}$ & $175,87 \pm 13,57$ & $188,60 \pm 14,64$ \\
$5000 \mathrm{mg} / \mathrm{kg} \mathrm{BB}$ & $163,33 \pm 17,72$ & $176,37 \pm 10,55$ \\
\hline
\end{tabular}

Nilai dinyatakan dalam mean \pm standar deviasi, $\mathrm{n}=3$.

Perubahan berat badan merupakan indikasi efek samping dari obat-obatan dan bahan kimia dan akan signifikan apabila perubahan tersebut melebihi $10 \%$ dari barat badan awal (Vaghasiya et al, 2010). Tidak adanya perbedaan yang signifikan antara kelompok kontrol dengan kelompok perlakuan sesuai dengan hasil penelitian Oraon dan Sinha (2012), yang menyebutkan bahwa ekstrak alkohol Biophytum reinwardtii (dosis 50, 75 dan $100 \mathrm{mg} / \mathrm{kg}$ ) tidak mempengaruhi berat badan tikus.

\section{Patologi}

Pemeriksaan gross patologi (makroskopis) tidak ditemukan adanya perubahan apapun pada setiap organ yang diperiksa. Berat absolut organ dan berat relatif organ per 100 gram berat badan yang diperoleh pada akhir masa observasi tidak menunjukkan perbedaan yang nyata dibandingkan dengan kelompok kontrol(Tabel 2 dan Tabel 3).

Tabel 2. Berat absolut organ kontrol dan perlakuan yang diberikan ekstrak rumput kebar

\begin{tabular}{lcccc}
\hline & Kontrol & $300 \mathrm{mg} / \mathrm{kg} \mathrm{BB}$ & $2000 \mathrm{mg} / \mathrm{kg} \mathrm{BB}$ & $5000 \mathrm{mg} / \mathrm{kg} \mathrm{BB}$ \\
\hline Otak & $1,73 \pm 0,06$ & $1,77 \pm 0,15$ & $1,77 \pm 0,06$ & $1,83 \pm 0,06$ \\
Jantung & $0,63 \pm 0,06$ & $0,73 \pm 0,15$ & $0,70 \pm 0,10$ & $0,67 \pm 0,12$ \\
Paru & $1,60 \pm 0,10$ & $1,50 \pm 0,17$ & $1,80 \pm 0,44$ & $1,60 \pm 0,10$ \\
Hepar & $6,90 \pm 0,40$ & $6,83 \pm 1,19$ & $6,80 \pm 1,13$ & $5,83 \pm 1,40$ \\
Lambung & $2,83 \pm 0,45$ & $2,47 \pm 1,03$ & $2,70 \pm 0,62$ & $2,47 \pm 1,32$ \\
Usus & $15,13 \pm 1,91$ & $14,63 \pm 1,16$ & $15,03 \pm 2,84$ & $13,37 \pm 1,74$ \\
Ginjal & $1,17 \pm 0,15$ & $1,17 \pm 0,15$ & $1,27 \pm 0,23$ & $1,17 \pm 0,06$ \\
Limpa & $0,43 \pm 0,06$ & $0,50 \pm 0,00$ & $0,50 \pm 0,10$ & $0,43 \pm 0,06$ \\
\hline
\end{tabular}

Berat badan merupakan indikator penting keadaan fisiologi dan patologi baik pada manusia maupun hewan. Berat organ relatif merupakan diagnosa dasar apakah suatu organ terpapar mengalami kerusakan atau tidak (Rajeh et al., 2012). Organ jantung, hepar, ginjal, limpha dan paru 
Uji Ekstrak n-Hexana Rumput Kebar (Biophytum petersianum Klotzsch) pada Tikus Wistar Hiperkolesterolemia

merupakan organ utama yang dipengaruhi oleh reaksi metabolik yang disebabkan oleh toksikan (Vaghasiya et al., 2010). Pengukuran terhadap berat absolut organ ditujukan untuk mengetahui ketoksikan nefrotik yang disebabkan oleh nefrotoksik (Dybing et al., 2002). Hal tersebut sesuai dengan hasil penelitian Oraon dan
Sinha (2012), yang menyebutkan bahwa ekstrak alkohol Biophytum reinwardtii (dosis 50, 75 dan 100 $\mathrm{mg} / \mathrm{kg}$ ) tidak menunjukkan perbedaan signifikan secara statistik, baik pada berat organ relatif maupun absolut antara kelompok perlakuan dengan kontrol.

Tabel 3. Berat relatif organ kontrol dan perlakuan yang diberikan ekstrak rumput kebar

\begin{tabular}{lcccc}
\hline & Kontrol & $300 \mathrm{mg} / \mathrm{kg} \mathrm{BB}$ & $2000 \mathrm{mg} / \mathrm{kg} \mathrm{BB}$ & $5000 \mathrm{mg} / \mathrm{kg} \mathrm{BB}$ \\
\hline Otak & $0,92 \pm 0,07$ & $0,97 \pm 0,03$ & $0,94 \pm 0,04$ & $1,04 \pm 0,03$ \\
Jantung & $0,34 \pm 0,01$ & $0,41 \pm 0,10$ & $0,37 \pm 0,03$ & $0,38 \pm 0,04$ \\
Paru & $0,85 \pm 0,10$ & $0,82 \pm 0,04$ & $0,96 \pm 0,26$ & $0,91 \pm 0,11$ \\
Hepar & $3,67 \pm 0,06$ & $3,74 \pm 0,35$ & $3,59 \pm 0,34$ & $3,31 \pm 0,11$ \\
Lambung & $1,56 \pm 0,32$ & $1,34 \pm 0,58$ & $1,46 \pm 0,44$ & $1,40 \pm 0,24$ \\
Usus & $8,02 \pm 0,58$ & $8,08 \pm 0,73$ & $7,93 \pm 0,96$ & $7,58 \pm 0,88$ \\
Ginjal & $0,62 \pm 0,07$ & $0,64 \pm 0,07$ & $0,67 \pm 0,07$ & $0,66 \pm 0,03$ \\
Limpa & $0,23 \pm 0,04$ & $0,28 \pm 0,03$ & $0,26 \pm 0,04$ & $0,25 \pm 0,02$ \\
\hline
\end{tabular}

Nilai dinyatakan dalam mean \pm standar deviasi, $n=3$,

\section{Kesimpulan}

Pemberian ekstrak n-hexana rumput kebar secara peroral tidak menimbulkan gejala toksisitas, kematian dan perubahan pada berat organ pada tikus dalam kondisi hiperkolesterol.

\section{Ucapan Terima Kasih}

Penelitian ini dibiayai oleh Kementerian Riset Teknologi dan Pendidikan Tinggi Republik Indonesia melalui skema hibah Penelitian Kerja Sama Antar Perguruan Tinggi (PKPT) dengan nomor kontrak: 089/SP2H/LT/DRPM/IV/2017.

\section{Daftar Pustaka}

Banerjee, A., Al Rashid, H., Rahman, A., Pal, T.K. (2014). In-vivo screening of ethanolic extract of Biophytum sensitivum DC leaves on peptic ulcer induced by aspirin in Wistar albino rats. International Journal of $P h$ ar m a c e u $t$ ic a $l$ a nd Phytopharmacological Research. 3(6): 418-422.

Bogoriani, N.W. (2008). Isolasi dan Identifikasi Glikosida Steroid dari Daun Andong (Cordyline terminalis Kunth). Jurnal Kimia 2(1).40-44.
BPOM. (2014). Pedoman Uji Toksisitas Nonklinis secara in vivo. Badan Pengawas Obat dan Makanan RI.

Chapagain, B.P., and Wiesman, Z. (2005). Larvicidal Activity of the Fruit Mesocarp Extract of Balanites aegyptiaca and its Saponin Fractions against Aedes aegypti. B. Dengue. 29.

Diantika, L. N dan Wiwiek L., (2016). Uji toksisitas akut ekstrak etanol benalu mangga (Dendrophthoe petandra) terhadap mencit swiss webster. IJPST. 3 (2): 53-65

Dybing, E., Doe, J., Groten, J., Kleiner, J., Brien, J.O., Renwick, A.G. (2002). Hazard characterization of chemicals in food and diet: dose response, mechanism and extrapolation issues. Food Chem Toxicol. 42:237-282.

Giknis M.L.A dan Clifford, C.B. (2008). Clinical laboratory parameters for $\mathrm{Crl}$ : WI (Han). Charles River Laboratories. Montreal. 8.

Halim, S.Z., Abdullah, N.R., Afzan, A., Abdul Rashid, B.A., Jantan, I. Dan Ismail, Z. (2011). Acute toxicity study of Carica papaya leaf extract in Sprague Dawley rats. Journal of Medicinal Plants Research. 5(20): 18671872. 
Kakade, R.T., Sandu, N and Senthilkumar, K.L. (2015). Evaluation of hypolipidemic and anti-obesity activities of Biophytum sensitivum Linn extracts on high fat diet induced hyperlipidemic rats. IJPCBS, 5(1): 357-360.

Mamoat, L.I. (2001). Minyak sawit mempercepat regresi aterosklerosis aorta pada kelinci hiperkolesterolemia ringan tetapi tidak apada yang hiperkolesterolemia berat. Tesis. Program Pascasarjana IPB.

OECD. (2008). OECD 407. Guidelines for the Testing of Chemicals. Repeated Dose 28-Day Oral Toxicity Study in Rodents.

Oraon A. and Sinha B.N. (2012). Sub chronic toxicity potential of the alcoholic extract of Biophytum reinwardtii whole plant. Journal of Natural Sciences Research. 2(6): 94-100.

Rajeh, M.A.B., Kwan, Y.P, Zakaria, Z., Latha, L.Y., Jothy, S.L.,Sasidharan, S. (2012). Acute toxicity impacts of Euphorbia hirta L extract on behavior, organs body weight index and histopathology of organs of the mice and Artemia salina. Pharmacognosy Res. 4(3): 170-177.

Renuka, C., Elavarasi, S., Saravanan, K and Revathi, G. (2015). Antihyperlipidemic activity of Biophytum sensitivum extracts in streptozotocin (STZ) induced diabetic albino rats, Int J Pharm Bio Sci. 6(4): 128135.
Sambodo, P., Tethool, A.N. dan Rumetor, S.D. (2015). Efek antikolesterol fraksi n-Heksana Rumput Kebar pada hewan model hiperlipidaemia. Jurnal Kedokteran Hewan. 9 (1): 59-60.

Sambodo, P., Nurhayati D., Purwaningsih, Airin, C.M. dan Susmiati, T. (2016). Parameter eritrosit pada uji toksisitas subkronis ekstrak nhexana rumput Kebar (Biophytum petersianum Klotzsch) endemik Papua. Proceedings: Peran Dokter Hewan dalam Peningkatan Kesehatan Hewan, Lingkungan dan Manusia. FKH UGM. 111-113.

Sambodo, P., Nurhayati, D., Purwaningsih, Trini, S. dan Claude, M.A., (2018). Subchronic toxicity test of kebar grass extract of nHexane (Biophytium Petersianum Klotzcch) on weight, ADG, and vital organ of Rat (Rattus norvegicus). J. Foof Pharm. Sci. $6: 14-16$

Vaghasiya, Y.K., Shukla, V.J., Chanda, S.V. (2010). Acute oral toxicity study of Pluchea arguta boiss extract in mice. J Pharmacol Toxicol. 6:113-123.

Yunita, E.A., Suprapti N.H. dan Hidayat J.W. (2009). Pengaruh ekstrak daun Teklan (Eupatorium riparium) terhadap mortalitas dan perkembangan larva Aedes aegypti. BIOMA.11.1. 